\title{
BAHAN AJAR KETERAMPILAN ELEKTRONIKA PADA KELOMPOK REMAJA DI DESA BONTOPANNU KAB. GOWA \\ Muhammad Riska ${ }^{1}$, Ratna Syam ${ }^{2}$ \\ JPTE FT UNM ${ }^{1}$, JKKPI SMK Negeri 8 Jeneponto $^{2}$ \\ Makassar \\ ${ }^{1}$ muhammadrbabodunm. ac. id \\ ${ }^{2}$ ratnasyam96@gmail.com
}

\begin{abstract}
Penelitian ini merupakan penelitian pengembangan bertujuan untuk mengetahui proses pengembangan, model konseptual, model fisik bahan ajar keterampilan elektronika dan efektifitas bahan ajar menggunakan program Autoplay 7.0 yang difokuskan untuk mengembangkan media pembelajaran pada kelompok remaja Desa Bontopannu, Kab. Gowa. Model pengembangan yang digunakan dalam penelitian ini adalah model pengembangan ADDIE yang dilakukan dengan beberapa tahap yakni (1) Analysis, (2) Design, (3) Development, (4) Implementation, (5) Evaluation. Media pembelajaran yang dikembangkan, telah divalidasi oleh dua orang ahli dengan mengalami revisi sehingga layak digunakan. Uji coba dilakukan sebanyak tiga kali yakni uji coba perorangan, uji coba kelompok kecil dan uji coba diperluas. Adapun hasil analisis respon pendidik menunjukkan bahwa media pembelajaran dalam katagori sangat baik. Sehingga disimpulkan bahwa media pembelajaran hasil pengembangan direspon positif oleh pelatih atau teman sejawat. Hasil penelitian menunjukkan bahwa pembelajaran menggunakan media Autoplay 7.0 pada teknik perawatan dan perbaikan alat telekomunikasi dinyatakan valid, praktis dan efektif penggunaan media pembelajaran di Desa Bontopannu Kab. Gowa. Hasil validasi lembar ahli materi dengan total nilai rata-rata 3,5 berada dalam katagori valid dan hasil validasi ahli media dengan total nilai rata-rata 3,23 berada pada katagori valid. Dari hasil analisis respon pelatih dan peserta pelatihan dalam katagori sangat baik, sehingga dinyatakan praktis digunakan dalam pembelajaran. Hasil analisis data aktivitas peserta pelatihan dan peserta pelatihan dikatagorikan sangat baik, sehingga dapat dinyatakan efektif digunakan dalam pembelajaran.
\end{abstract}

Keywords: Media Desain, Autoplay 7.0, Pengembangan, Efektif

\section{PENDAHULUAN}

Pemberdayaan masyarakat adalah proses pembangunan dimana masyarakat bernisiatif untuk memulai proses kegiatan sosial untuk memperbaiki situasi dan kondisi diri sendiri. Di sisi lain, salah satu kata kunci pada saat ini yang sering didengungan oleh semua lapisan masyarakat adalah kata peningkatan sumberdaya manusia. Kata tersebut mempunyai makna lebih spesifik lagi menyangkut bagaimana mengangkat kondisi masyarakat yang ada menjadi lebih baik dimasa mendatang.

Memberdayakan masyarakat pesisir tidaklah seperti memberdayakan kelompok-kelompok masyarakat lainnya, karena di dalam habitat pesisir terdapat banyak kelompok kehidupan masyarakat, di antaranya:

a. Masyarakat nelayan tangkap, adalah kelompok masyarakat pesisir yang mata pencaharian utamanya adalah menangkap ikan di laut. Kelompok ini dibagi lagi dalam dua kelompok besar, yaitu nelayan kelompok modern dan nelayan tangkap tradisional. Kedua kelompok ini dapat dibedakan dari jenis kapal atau peralatan yang digunakan dan jangkauan wilayah tangkapnya.

b. Masyarakat nelayan pengumpul atau bakul, adalah kelompok masyarakat pesisir yang bekerja disekitar tempat pendaratan dan pelelangan ikan. Mereka akan mengumpulkan ikan-ikan hasil tangkapan baik melalui pelelangan maupun dari sisi ikan yang tidak terlelang yang selanjutnya dijual ke masyarakat sekitarnya atau dibawah ke pasarpasar lokal. Umumnya yang menjadi pengumpul ini adalah kelompok masyarakat pesisir perempuan.

Masyarakat nelayan atau yang bermata pencaharian sebagai nelayan adalah masyarakat yang hidup dekat air. Air itulah yang digunakan sebagai sumber penghasilan atau penghidupan kesehariannya. Dalam kenyataannya, ada kalanya seorang menjadikan aktifitas menagkap ikan sebagai mata pencaharian pokok dan ada pula yang hanya dijadikan sebagai kegiatan tambahan yang memungkinkannya bisa meningkatkan pendapatan untuk menopang hidup dan terpenuhinya kebutuhan.

Dalam hal ini, masyarakat pesisir atau kelompok remaja tak lepas dari pendidikan. Jadi dapat disimpulkan proses belajar mengajar tidak memandang profesi, belajar adalah kebutuhan hidup yang "self-generating", yang 
mengupayakan dirinya sendiri, karena sejak lahir manusia memiliki dorongan melangsungkan hidupnya. Manusia belajar terus menerus untuk mampu mencapai kemandirian dan beradaptasi terhadap berbagai perubahan lingkungan. (Semiawan.,Conny R. 2007)

Proses belajar mengajar didasarkan pada Permendiknas Nomor 24 Tahun 2007 tentang sarana dan prasarana menjelaskan bahwa Standar Nasional Pendidikan yang berkaitan dengan kriteria minimal tentang ruang belajar, tempat berolah raga, tempat beribadah, perpustakaan, laboratorium, bengkel kerja, tempat bermain, tempat berkreasi dan berekreasi, serta sumber belajar lain yang diperlukan untuk menunjang proses pembelajaran, termasuk penggunaan teknologi informasi dan komunikasi. Selanjutnya diperkuat dengan Keppres No. 50/2000 tentang Pengadaan Tim Koordinasi Telematika Indonesia yang mengacu pada pemanfaatan ICT dalam berbagai sektor dan aspek kehidupan termasuk dalam bidang pendidikan (Rusman, 2011).

Penggunaan TIK dalam proses pembelajaran mempunyai kelebihan, yakni mempermudah dan mempercepat kerja kelompok remaja pesisir pantai, juga menyenangkan karena kelompok remaja pesisir pantai berinteraksi dengan warna-warna, gambar, suara, video, dan sesuatu yang instan. Situasi dan kondisi yang menyenangkan ini sebenarnya menjadi faktor yang sangat penting dan esensial untuk mencapai efektivitas pembelajar karena mampu mengkaitkan emosi positif dalam proses belajar. Dengan demikian, penggunaan media audio-visual dalam hal ini penggunaan aplikasi komputer tentunya dapat menciptakan suasana pembelajaran yang menyenangkan dan berkesan. Proses pembelajaran yang terjadi di dalam kelas merupakan suatu aktivitas mentransformasikan pengetahuan, sikap, dan keterampilan. Pembelajaran dapat diartikan sebagai perubahan dalam kemampuan, perilaku atau sikap kelompok remaja pesisir yang relatif permanen sebagai akibat pengalaman ataupun pelatihan/perubahan kemampuan yang hanya berlangsung sekejap dan kemudian kembali lagi ke perilaku semula maka hal tersebut menunjukkan belum terjadinya peristiwa pembelajaran, walaupun mungkin telah terjadi pengajaran oleh pendidik. Tugas seorang masyarakat adalah membuat proses pembelajaran pada masyarakat pesisir berlangsung secara efektif.

Mulyasa (2006) mengemukakan bahwa pendidikan yang memegang peranan penting baik dalam perencanaan maupun dalam pelaksanaan kurikulum. Dengan demikian, minimal ada tiga peran utama yang harus kelompok remaja pesisir, yaitu pendidikansebagai perencana, sebagai penyampai informasi, dan pendidikansebagai evaluator. Sebagai perencana pengajaran, sebelum proses pengajaran pendidikanharus menyiapkan berbagai hal yang diperlukan, seperti misalnya materi pelajaran apa yang harus disampaikan, bagaimana cara penyampaiannya, media apa yang harus di gunaka. Sebagai penyampai informasi, masyarakat dapat menggunakan berbagai model pembelajaran yang sesuai dengan materi. Sedangkan sebagai evaluator pendidik berperan dalam menentukan alat evaluasi keberhasilan pengajaran.

Tantangan bagi para kelompok remaja pesisir, untuk menciptakan pembelajaran yang menggairahkan dan menyenangkan bagi masyarakat. Untuk itu diperlukan pendidik yang profesional, kreatif, dan menyenangkan sehingga mampu menciptakan iklim pembelajaran yang kondusif, suasana belajar yang menantang, dan mampu membelajarkan dengan menyenangkan. Sebagai pelaksana kurikulum, masyarakat memerlukan perangkat pembelajaran yang lebih operasional seperti media, dan tes. Pada umumnya, masyarakat belum mampu membuat suatu media pembelajaran audio-visual untuk digunakan dalam suatu pembelajaran, khususnya yang berbantuan komputer.

Pendidik sebaiknya menggunakan aturan tertentu dalam membuat dan mengembangkan suatu perangkat pembelajaran, agar perangkat pembelajaran yang dihasilkan dapat berhasil guna dalam pembelajaran. Artinya, dengan perangkat pembelajaran yang dihasilkan tujuan pembelajaran dapat tercapai.

Menurut Sapto Haryoko (2009) pembelajaran pada hakikatnya adalah proses komunikasi yang bertujuan untuk penyampian pesan/informasi sehingga dapat merangsang pikiran, perasaan dan minat serta perhatian masyarakat pesisir. Pada proses pembelajaran, pengembangan bahan ajar dapat melalui berbagai cara dan salah satunya melalui optimalisasi media. Media yang digunakan untuk memperlancar komunikasi dalam proses belajar mengajar.

Menurut Sapto Haryoko (2009), Media audiovisual merupakan salah satu media yang digunakan dalam pembelajaran dan diyakini dapat lebih menggairahkan animo kelompok remaja pesisir dalam proses pembelajaran. Terdapat beberapa aspek yang membuat media audio-visual dapat digunakan sebagai sarana alternatif dalam mengoptimalkan proses pembelajaran, antara lain: (1) mudah dikemas dalam proses pembelajaran, (2) lebih menarik untuk pembelajaran, dan (3) dapat diperbaiki setiap saat. Hal tersebut sejalan dengan hasil penelitian yang telah dilakukan Sapto Haryoko (2009) yang menemukan bahwa hasil belajar mahasiswa teknik jaringan komputer yang diajar dengan menggunakan media audio-visual memiliki skor yang jauh lebih tinggi dibanding dengan mahasiswa teknik jaringan komputer yang diajar menggunakan pendekatan konvensional.

Berdasarkan uraian diatas tersebut, peneliti berkeinginan mengembangkan media pembelajaran audio-video yang diharapkan dapat memberikan pengalaman belajar bagi masyarakat pesisir dengan menampilkan komponen-komponen dari media audiovisual. Pengembangan media pembelajaran harus diarahkan kepada efektivitas pembelajaran masyarakat pesisir. Dengan demikian, pendidik harus mampu memilih dan menggunakan media yang tepat pada materi pengembangan media pembelajaran keterampilan 
elektronika berbasis audio-video agar tercapai tujuan pembelajaran yang optimal.

Berdasarkan uraian latar belakang masalah yang dikemukakan diatas secara operasional masalah dalam penelitian ini dirumuskan dalam bentuk pertanyaan yaitu: (1) Bagaimanakah proses pengembangan bahan ajar keterampilan elektronika pada kelompok remaja Desa Bontopannu Kab. Gowa. (2) Bagaimanakah model konseptual dan model fisik bahan ajar keterampilan elektronika pada kelompok remaja Desa Bontopannu Kab. Gow. (3) Apakah bahan ajar yang dikembangkan efektif digunakan bagi kelompok remaja Bontopannu Kab. Gowa.

\section{METODE PENELITIAN}

Penelitian ini adalah penelitian pengembangan (Research and Development) yang mengembangkan perangkat pembelajaran berbasis audio-visual. Model yang menjadi acuan dalam penelitian ini adalah model ADDIE yang terdiri dari lima fase Analysis, Desain, Development, Implementation, dan Evaluation (Benny, 2009).

Tempat penelitian yaitu di Desa Bontopannu Kab. Gowa dengan subjek penelitiannya adalah masyarakat/ kelompok remaja. Waktu pelaksanaan penelitan pada 2019 .

Penelitian ini akan mengkaji pengembangan media pembelajaran berbasis audio-video keterampilan elektronika dasar dengan mengadaptasi model pengembangan model ADDIE yang terdiri dari lima fase Analysis, Design, Development, Implementation, dan Evaluation (Benny, 2010). Penelitian ini dilaksanakan dengan tiga tahap yaitu tahap persiapan, tahap pengembangan, dan tahap uji coba dan evaluasi.

Menurut Benny (2010) model pengembangan ADDIE terdiri atas 5 langkah pokok, yaitu Analysis, Design, Development, Implementation, dan Evaluation.Tahapan penelitian tersebut adalah sebagai berikut.

\section{A. Analysis (analisis)}

Kegiatan utama pada tahap ini adalah menganalisis perlunya pengembangan media / metodepembelajaran berbasis audio-visual baru dan menganalisis kelayakan dan syarat - syarat pengembangan media pembelajaran berbasis audio-visual. Pengembangan media pembelajaran pembelajaran berbasis audio-visual diawali oleh adanya masalah dalam media pembelajaran yang sudah diterapkan. Setelah analisis masalah perlunya pengembangan media pembelajaran berbasis audio -visual, peneliti juga perlu menganalisis kelayakan dan syarat - syarat pengembangan mediapembelajaran berbasis audio-visual tersebut.

Langkah analisis terdiri atas dua tahap, yaitu analisis kinerja (performance analysis)dan analisis kebutuhan (need analysis). Tahap pertama, yaitu analisis kerja dilakukan untuk mengetahui dan mengklarifikasi apakah masalah kinerja yang dihadapi memerlukan solusi berupa penyelenggaraan program pembelajaran atau perbaikan manajemen. Pada tahap kedua, yaitu analisis kebutuhan, merupakan langkah yang diperlukan untuk menentukan kemampuan-kemampuan atau kompetensi yang perlu dipelajari oleh pebelajar untuk meningkatkan kinerja atau prestasi belajar. Hal ini dapat dilakukan apabila program pembelajaran dianggap solusi dari masalah pembelajaran yang sedang dihadapi.

\section{B. Design (Desain)}

Kegiatan ini merupakan proses sistematik yang dimulai dari menetapkan tujuan belajar, merancang skenario atau kegiatan belajar mengajar, merancang perangkat pembelajaran, merancang materi pembelajaran dan alat evaluasi hasil belajar. Rancangan media/metode pembelajaran ini masih bersifat konseptual dan akan mendasari proses pengembangan berikutnya. Pada langkah ini diperlukan adanya klarifikasi program pembelajaran yang didesain sehingga program tersebut dapat mencapai tujuan pembelajaran seperti yang diharapkan.

\section{Development (Pengembangan)}

Development dalam model ADDIE berisi kegiatan realisasi rancangan produk. Dalam tahap desain, telah disusun kerangka konseptual media/metode pembelajaran berbasis audio-visual. Dalam tahap pengembangan, kerangka yang masih konseptual tersebut direalisasikan menjadi produk yang siap diimplementasikan. Langkah pengembangan instrumen atau alat ukur untuk menentukan tingkat kelayakan media yang akan dipakai;

1. Validasi instrument pengambilan data dilakukan oleh ahli materi dalam pengembangan media.

2. Melakukan validasi isi dan koherensi terhadap media yang telah dikembangkan oleh ahli media.

3. Melakukan uji coba terhadap subjek penelitian, meliputi uji coba keterbacaan oleh beberapa remaja, uji coba kelompok kecil, dan uji coba lebih luas.

\section{Implementation (Implementasi)}

Pada tahap ini diimplementasikan media/metode yang telah dikembangkan pada situasi yang nyata yaitu di kelas/ ruangan. Selama implementasi, rancangan media/metode yang telah dikembangkan diterapkan pada kondisi yang sebenarnya. Setelah penerapan, dilakukan evaluasi awal untuk memberi umpan balik pada penerapan media/metode berikutnya.

\section{E. Evaluation (Evaluasi)}

Evaluasi dilakukan dalam dua bentuk yaitu evaluasi formatif dan sumatif. Evaluasi formatif dilaksanakan pada akhir setiap tahap sedangkan evaluasi sumatif dilakukan setelah kegiatan berakhir secara keseluruhan.Revisi dibuat sesuai dengan hasil evaluasi atau kebutuhan yang belum dapat dipenuhi oleh media/metode tersebut. 


\section{TINJAUAN PUSTAKA}

\section{A. Bahan Ajar}

1) Pengembangan Bahan Ajar: Menurut Panen dan Purwanto (2004) Bahan ajar mempunyai struktur dan urutan yang sistematis, menjelaskan tujuan instruksional yang akan dicapai, memotivasi peserta didik untuk belajar, mengantisipasi kesukaran belajar peserta didik sehingga menyediakan bimbingan bagi peserta didik untuk mempelajari bahan tersebut, memberikan latihan yang banyak, menyediakan rangkuman, dan secara umum berorientasi pada peserta didik secara individual (learner oriented).

Menurut Gafur (2004) bahan ajar adalah pengetahuan, keterampilan dan sikap yang harus diajarkan oleh guru dan dipelajari oleh siswa. Bahan ajar tersebut berisi materi pelajaran yang harus dikuasai oleh guru dan disampaikan kepada siswa. Bahan ajar merupakan salah satu bagian dari sumber belajar yang dapat diartikan sesuatu yang mengandung pesan pembelajaran, baik yang diniati secara khusus maupun bersifat umum yang dapat dimanfaatkan untuk kepentingan pembelajaran (Mulyasa 2006). Dengan kata lain bahan ajar adalah segala bentuk bahan yang digunakan untuk membantu guru/instruktur dalam melaksanakan kegiatan pembelajaran di kelas. Bahan yang dimaksud bisa berupa bahan tertulis maupun bahan tidak tertulis.

Menurut Panen dan Purwanto (2004) bahan ajar berbeda dengan buku teks. Perbedaan antara bahan ajar dengan buku teks tidak hanya terletak pada format, tata letak dan perwajahannya, tetapi juga pada orientasi dan pendekatan yang digunakan dalam penyusunannya. Buku teks biasanya ditulis dengan orientasi pada struktur dan urutan berdasarkan bidang ilmu (content oriented) untuk dipergunakan oleh dosen atau guru dalam mengajar (teaching oriented).

Beberapa pendapat di atas, dapat disimpulkan bahwa bahan ajar yang baik dirancang sesuai dengan prinsipprinsip instruksional. Guru dapat menulis sendiri bahan ajar yang ingin digunakan dalam kegiatan belajar mengajar (KBM). Namun, guru juga dapat memanfaatkan buku teks atau bahan dan informasi lainnya yang sudah ada di pasaran untuk dikemas kembali atau ditata sedemikian rupa sehingga dapat menjadi bahan ajar. Bahan ajar biasanya dilengkapi dengan pedoman untuk siswa dan guru. Pedoman berguna untuk mempermudah siswa dan guru mempergunakan bahan ajar.

\section{2) Faktor Pertimbangan Pengembangan Bahan}

Ajar: Bahan ajar mempunyai peran penting dalam proses pembelajaran, yaitu acuan yang digunakan oleh penatar atau petatar. Bagi petatar bahan ajar menjadi acuan yang diserap isinya sehingga dapat menjadi pengetahuan dan bagi penatar bahan ajar ini menjadi acuan dalam menyampaikan keilmuannya.

Pengembangan bahan ajar oleh penatar membutuhkan kreativitas untuk membuat sesuatu yang lain, unik, juga membutuhkan pengetahuan tentang lingkungan sekitarnya agar bahan ajar yang dikembangkan sesuai dengan ketersediaan bahan/materi di sekitarnya. Di samping itu penatar juga harus memiliki pengetahuan tentang beberapa faktor yang perlu dipertimbangkan dalam pengembangan bahan ajar seperti kecermatan isi, ketepatan cakupan, ketercernaan, penggunaan bahasa, ilustrasi, perwajahan/pengemasan serta kelengkapan komponen bahan ajar.

a. Kecermatan Isi

Kecermatan isi adalah validitas/ kesahihan isi atau kebenaran ini secara keilmuan, dan keselarasan isi. Atau kebenaran isi berdasrkan sistem nilai yang dianut oleh suatu masyarakat atau bangsa.

b. Ketepatan Cakupan

Kecermatan isi berfokus pada kebenaran isi secara keilmuan dan sistem nilai yang berlaku di masyarakat. Maka ketepatan cakupan berhubungan dengan isi bahan ajar dari sisi keluasan dan kedalaman isi atau materi serta keutuhan konsep berdasarkan bidang ilmu.

c. Ketercernaan Bahan Ajar

Bahan ajar, menggunakan media apapun, harus memiliki tingkat ketercernaan yang tinggi. Artinya bahan ajar dapat dipahami dan isinya dapat dimengerti oleh peserta dengan mudah. Ada enam hal yang mendukung tingkat ketercernaan bahan ajar, sebagai berikut:

1) Pemaparan yang logis

Bahan ajar dipaparkan secara logis, misalnya mulai dari yang umum ke yang khusus atau sebaliknya (deduktif atau induktif), dari yang mudah ke yang sukar, atau dari yang inti ke yang pendukung.

2) Penyajian Materi yang runtut

Bahan ajar disajikan secara sistematis, tidak meloncat-loncat. Keterkaitan antar materi/topik dijelaskan dengan cermat, kemudian setiap topik disajikan secara sistematis dengan strategi penyajian uraian, contoh dan latihan, atau contoh, latihan, penyajian uraian, atau penyajian uraian, latihan, contoh (PCL - CLP - PLC).

3) Contoh dan Ilustrasi

Untuk menyajikan suatu topik dan memaparkan suatu pokok bahasan diperlukan contoh dan ilustrasi yang dapat membantu dan mempermudah pemahaman peserta. Dalam penyajian topik atau konsep yang bersifat abstrak, contoh dan ilustrasi memiliki peran yang sangat penting.

4) Alat bantu yang memudahkan

Bahan ajar perlu memiliki alat bantu yang dapat mempermudah peserta dalam mempelajari bahan ajar tersebut, yang dikenal dengan nama Mnemonic Devices (alat bantu mengingat atau belajar).

5) Format yang tertib dan konsisten

Bahan ajar perlu memelihara ketertiban dan konsistensi agar mudah dikenali, diingat, dan 
dipelajari oleh peserta. Misalnya, jika guru menggunakan kertas merah untuk lembar kerja peserta, maka seterusnya gunakanlah warna kertas merah untuk LKS, jangan gunakan warna merah untuk komponen lain dalam bahan ajar. Dengan demikian, setiap kali peserta melihat warna kertas merah, maka peserta akan menandai sebagai LKS.

6) Penjelasan Relevansi Dan Manfaat Bahan Ajar Dalam bahan ajar perlu ada penjelasan tentang manfaat dan kegunaan bahan ajar dalam mata tataran. Bahan ajar dapat berperan sebagai bahan utama yang akan digunakan dalam pembelajaran di kelas, atau sebagai alat bantu peserta belajar mandiri di rumah (buku kerja, paket kerja mandiri), atau juga sebagai alat bantu peserta belajar dalam kelompok. Peran ini perlu dijelaskan kepada peserta dengan cermat, sehingga peserta dapat menggunakan bahan ajar dengan jelas.

3) Pengunaan Bahasa: Dalam mengembangkan bahan ajar, penggunaan bahasa menjadi salah satu faktor yang penting. Penggunaan bahasa, yang meliputi pemilihan ragam bahasa, pemilihan kata, penggunaan kalimat efektif, dan penyusunan paragraph yang bermakna, sangat berpengaruh terhadap manfaat bahan ajar. Walaupun isi bahan ajar Anda sudah cermat, menggunakan format yang konsisten, serta dikemas dengan menarik, namun jika bahasa yang Anda gunakan tidak dimengerti oleh peserta, maka bahan ajar Anda tidak akan bermakna apa-apa. Penggunaan bahasa menjadi faktor penting, bukan hanya dalam pengembangan bahan ajar cetak seperti buku kerja peserta, lembar kerja peserta, tetapi juga dalam pengembangan bahan ajar noncetak, seperti kaset audio, video, bahan ajar berbasiskan komputer, dan lain-lain.

Ragam Bahasa mengacu pada ragam bahasa baku atau formal dan ragam bahasa nonformal atau komunikatif. Ragam bahasa baku banyak digunakan dalam laporan penelitian, karya ilmiah, surat-surat resmi, buku teks, siaran pers, dan lain-lain. Bahasa baku dapat dimengerti dengan baik oleh pembacanya, karena sama sekali tidak dipengaruhi oleh dialek bahasa sehari-hari maupun dialek bahasa daerah. Namun demikian, tulisan yang menggunakan ragam bahasa baku terkesan sangat kaku, formal dan cenderung membosankan. Oleh karena itu, ragam bahasa baku jarang digunakan dalam pengembangan bahan ajar.

Bahan ajar yang baik diharapkan dapat memotivasi peserta untuk membaca, mengerjakan tugas-tugasnya, serta menimbulkan rasa ingin tahu peserta untuk melakukan eksplorasi lebih lanjut tentang topik yang dipelajarinya. Dengan demikian, ragam bahasa yang digunakan dalam bahan ajar biasanya ragam bahasa nonformal atau bahasa komunikatif yang lugas dan luwes. Dalam bahasa komunikatif, pembaca diajak untuk berdialog secara intelektual melalui sapaan, pertanyaan, ajakan, dan penjelasan, seolah-olah dialog dengan orang kedua itu benar-benar terjadi. Penggunaan bahasa komunikatif akan membuat peserta merasa seolah-olah berinteraksi (pseudo-interaction) dengan gurunya sendiri melalui tulisan-tulisan yang disampaikan dalam bahan ajar.

Ragam bahasa komunikatif yang sebaiknya digunakan dalam penulisan atau pengembangan bahan ajar sangat dipengaruhi oleh pemilihan kata serta penggunaan kalimat yang efektif. Walaupun ragam bahasa komunikatif yang digunakan, hendaknya kaidah bahasa yang baik dan benar tidak ditinggalkan atau dilanggar. Hal ini sangat perlu sebagai salah satu persyaratan dari keterbacaan bahan ajar yang ditulis atau dikembangkan.

\section{B. Media Audio-Video}

1) Pengertian Media Pembelajaran: Kemajuan ilmu pengetahuan dan teknologi, khususnya teknologi informasi, sangat berpengaruh terhadap penyusunan dan implementasi strategi pembelajaran.Kemajuan para pendidikdapat menggunakan berbagai media sesuai dengan kebutuhan dan tujuan pembelajaran.

Menurut Sanjaya (2006) Proses pembelajaran merupakan proses komunikasi, dalam suatu proses komunikasi selalu melibatkan tiga komponen pokok, yaitu komponen pengirim pesan (pendidik), komponen penerima pesan (masyarakat pesisir), dan komponen pesan itu sendiri yang biasanya berupa materi pelajaran. Kadang-kadang dalam proses pembelajaran terjadi kegagalan komunikasi. Untuk menghindari semua itu, maka guru dapat menyusun strategi pembelajaran dengan memanfaatkan berbagai media dan sumber belajar.

Menurut Angkowo (2007) Kata media berasal dari bahasa Latin Medius yang secara harfiah berarti tengah, perantara, atau pengantar. Tetapi secara lebih khusus, pengertian media dalam proses pembelajaran diartikan sebagai alat-alat grafis, fotografis, atau elektronis untuk menangkap, memproses, dan menyusun kembali informasi visual atau verbal. Media juga dapat diartikan sebagai segala sesuatu yang dapat dipergunakan untuk menyalurkan pesan, merangsang pikiran, perasaan, perhatian,dan kemauan peserta didik, sehingga dapat terdorong terlibat dalam proses pembelajaran.

Menurut Gerlach \& Ely (1980) mengatakan bahwa media apabila dipahami secara garis besar adalah manusia, materi, atau kejadian yang membangun kondisi yang membuat siswa mampu memperoleh pengetahuan, keterampilan atau sikap. Secara khusus, pengertian media dalam proses belajar mengajar cenderung diartikan sebagai alat-alat grafis, photografis, atau elektronis untuk menangkap, memproses dan menyusun kembali informasi visual atau verbal.

Media adalah segala alat fisik yang dapat menyajikan pesan serta merangsang siswa untuk belajar (Briggs, 1997). Kemudian pada pendapat yang lain mengemukakan bahwa media merupakan teknologi pembawa informasi atau pesan instruksional yang dapat 
dimanipulasi, dilihat, didengar dan dibaca. (Schramm, 1964).

Media adalah sebuah alat yang mempunyai fungsi menyampaikan pesan (Bovee and Thull, 1997). Media merupakan bentuk jamak dari kata "medium" yang berasal dari bahasa latin yang berarti "antara". Istilah media dapat kita artikan sebagai segala sesuatu yang menjadi perantara atau penyampai informasi dari pengirim pesan kepada penerima pesan. Berbicara mengenai media tentunya kita akan mempunyai cakupan yang sangat luas, oleh karena itu saat ini masalah media kita batasi ke arah yang relevan dengan masalah pembelajaran saja atau yang dikenal sebagai media pembelajaran.

Secara umum media merupakan kata jamak dari "medium", yang berarti perantara atau pengantar.Kata media berlaku untuk berbagai kegiatan atau usaha, seperti media dalam penyampaian pesan, media pengantar magnet atau panas dalam bidang teknik.Istilah media digunakan juga dalam bidang pengajaran atau pendidikan sehingga istilahnya menjadi media pendidikan atau media pembelajaran.

Berdasarkan uraian beberapa batasan tentang media diatas, berikut ciri-ciri umum yang terkandung pada tiap batasan itu; a) Pendidikan memiliki pengertian fisik yang dewasa ini dikenal sebagai hardware (perangkat keras) yaitu sesuatu benda yang dapat dilihat, didengar atau diraba dengan pancaindera. b) Pendidikan memiliki pengertian non-fisik yang dikenal sebagai software (perangkat lunak) yaitu kandungan pesan yang terdapat dalam perangkat keras yang merupakan isi yang ingin disampaikan kepada peserta didik (Arsyad, 2002).

2) Macam-Macam Media Pembelajaran Dan Karakteristiknya: Perkembangannya media pembelajaran mengikuti perkembangan teknologi. Teknologi yang paling tua dimanfaatkan dalam proses belajar mengajar adalah percetakan yang bekerja atas dasar mekanis. Kemudian lahir teknologi audio-visual yang menggabungkan penemuan mekanis dan elektronis untuk tujuan pembelajaran.Teknologi yang terakhir muncul adalah teknologi mikroprosesor (otak komputer) yang melahirkan pemakaian komputer dan pencipta teknologi ini adalah orang nomor 1 terkaya di dunia yaitu Bill Gates sekaligus merupakan pemilik perusahaan mikroprosesor terbesar Microsoft. Menurut Rusman (2012)terdapat lima jenis media yang dapat digunakan dalam pembelajaran, antara lain:

a. Media visual, yaitu media yang hanya dapat dilihat dengan menggunakan indra penglihatan yang terdiri atas media yang dapat diproyeksikan dan media yang tidak dapat diproyeksikan yang biasanya berupa gambar diam atau gambar bergerak.

b. Media audio, yaitu media yang mengandung pesan dalam bentuk auditif yang dapat merangsang pikiran, perasaan, perhatian, dan kemauan para peserta didik untuk mempelajari bahan ajar. Contoh dari media audio ini adalah program kaset suara dan program radio. c. Media audio-visual, yaitu media yang merupakan kombinasi audio dan visual atau biasa disebut media pandang-dengar. Contoh dari media audio-visual adalah program video/televisi pendidikan, video/televisi instruksional, dan program slide suara (slide sound).

d. Media kelompok penyaji yang terdiri dari tujuh kelompok, yaitu; $\quad$ (1) kelompok pertama; grafis, bahan cetak, dan gambar diam, (2) kelompok kedua; media proyeksi diam, (3) kelompok media audio, (4) kelompok keempat; media video, (5) kelompok kelima; media gambar hidup / film, (6) kelompok keenam; media televisi, dan (7) kelompok ketujuh; multimedia.

e. Media objek dan media interaktif berbasis komputer. Media objek merupakan media tiga dimensi yang menyampaikan informasi tidak dalam bentuk penyajian, melainkan melalui ciri fisik sendiri, seperti ukuran, bentuk, berat, susunan, warna, fungsi, dan sebagainya. Media ini dapat dibagi menjadi dua kelompok, yaitu media objek sebenarnya dan media objek pengganti. Sedangkan media interaktif berbasis komputer adalah media yang menuntut peserta didik untuk berinteraksi selain melihat maupun mendengarkan. Contoh media interaktif berbasis komputer adalah program interaktif dalam pembelajaran berbasis komputer.

Menurut Sanjaya (2006) media pembelajaran dapat diklasifikasikan menjadi beberapa klasifikasi tergantung dari sudut mana melihatnya.

a. Dilihat dari sifatnya, media dapat dibagi ke dalam:

1) Media auditif, yaitu yang hanya dapat didengar saja atau media yang memiliki unsur suara, seperti radio dan rekaman suara.

2) Media visual, yaitu media yang hanya dapat dilihat saja, tidak mengandung unsur suara. Yang termasuk ke dalam media ini adalah film slide, foto, transparansi, lukisan, gambar, dan berbagai bentuk bahan yang dicetak seperti media grafis dan lain sebagainya.

3) Media audio-visual, yaitu jenis media yang selain mengandung unsur suara juga mengandung unsur gambar yang bisa dilihat. Misalnya rekaman video, berbagai ukuran film, slide suara, dan lain sebagainya. Kemampuan media ini dianggap lebih baik dan lebih menarik, sebab mengandung kedua unsur jenis media yang pertama dan kedua.

b. Dilihat dari kemampuan jangkauannya, media dapat pula dibagi ke dalam:

1) Media yang memiliki daya liput yang luas dan serentak, seperti radio dan televisi. Melalui media ini siswa dapat mempelajari hal-hal atau kejadian-kejadian yang aktual secara serentak tanpa harus menggunakan ruangan khusus.

2) Media yang mempunyai daya liput yang terbatas oleh ruang dan waktu, seperti film slide, film, video, dan lain sebagainya. 
c. Dilihat dari cara atau teknik pemakaiannya, media dapat dibagi ke dalam:

1) Media yang diproyeksikan, seperti film, slide, film strip, transparansi, dan lain sebagainya. Jenis media yang demikian memerlukan alat proyeksi khusus seperti film projector untuk memproyeksikan film, slide projector untuk memproyeksikan filmslide, overhead projector $(O H P)$ untuk memproyeksikan transparansi. Tanpa dukungan alat proyeksi semacam ini, maka media semacam ini, maka media semacam ini tidak akan berfungsi apa-apa.

2) Media yang tidak diproyeksikan seperti gambar, foto, lukisan, radio, dan lain sebagainya.

\section{HASIL PENELITIAN DAN PEMBAHASAN}

Pengambilan data dilakukan menggunakan instrument berupa angket yang telah divalidasi oleh ahli materi dan ahli media dalam pengembangan media. Jenis instrumen yang divalidasi yaitu; angket respon peserta pelatihan, angket respon pelatih, angket aktivitas tabel, angket aktivitas pelatih, soal pre-post test.

Hasil nilai rata-rata total validasi angket respon tabel adalah 3.00. Angket respon tabel sesuai tabel katagori validasi di katagorikan valid. Sehingga angket tersebut dapat digunakan dalam penelitian. Rangkuman hasil validasi angket respon tabel dapat dilihat pada tabel I.

Tabel I

Hasil Validasi Angket Respon Peserta Pelatihan

\begin{tabular}{|c|c|c|c|}
\hline No & URAIAN & RERATA & KET \\
\hline \multirow{3}{*}{ I } & Aspek Petunjuk & & \\
\hline & $\begin{array}{l}\text { 1. Petunjuk lembar angket respon peserta didik } \\
\text { dinyatakan dengan jelas. }\end{array}$ & 3 & Valid \\
\hline & 2. Kriteria penilaian dinyatakan dengan jelas. & 3 & Valid \\
\hline \multicolumn{2}{|r|}{ Nilai Rata-rata Aspek I } & 3 & Valid \\
\hline \multirow[t]{4}{*}{ II } & Aspek Cakupan & & \\
\hline & $\begin{array}{l}\text { 1. Sesuai dengan tujuan angket respon peserta } \\
\text { didik }\end{array}$ & 3 & Valid \\
\hline & 2. Pernyataan sesuai dengan indikator & 3 & Valid \\
\hline & 3. Batasan peryataan dirumuskan dengan jelas & 3 & Valid \\
\hline \multicolumn{2}{|r|}{ Nilai Rata-rata Aspek II } & 3 & Valid \\
\hline \multirow{3}{*}{ III } & \multicolumn{2}{|l|}{ Aspek Bahasa } & \\
\hline & $\begin{array}{l}\text { 1. Menggunakan bahasa Indonesia yang benar } \\
\text { dan jelas }\end{array}$ & 3 & Valid \\
\hline & $\begin{array}{l}\text { 2. Menggunakan Kalimat yang sederhana dan } \\
\text { mudah dimengerti. }\end{array}$ & 3 & Valid \\
\hline \multicolumn{2}{|r|}{ Nilai Rata-rata Aspek III } & 3 & Valid \\
\hline \multicolumn{2}{|r|}{ Rata-rata Total } & 3 & Valid \\
\hline
\end{tabular}

Tabel II

Hasil Validasi Angket Respon Pelatih

\begin{tabular}{|c|c|c|c|}
\hline NO & URAIAN & RERATA & KET \\
\hline \multirow{3}{*}{ I } & Aspek Petunjuk & & \\
\hline & $\begin{array}{l}\text { 1. Petunjuk lembar angket respon peserta } \\
\text { didik dinyatakan dengan jelas. }\end{array}$ & 3 & Valid \\
\hline & $\begin{array}{l}\text { 2. Kriteria penilaian dinyatakan dengan } \\
\text { jelas. }\end{array}$ & 3 & Valid \\
\hline & Nilai Rata-rata Aspek I & 3 & Valid \\
\hline \multirow{4}{*}{ II } & Aspek Cakupan & & \\
\hline & $\begin{array}{l}\text { 1. Sesuai dengan tujuan angket respon } \\
\text { peserta didik }\end{array}$ & 3 & Valid \\
\hline & 2. Pernyataan sesuai dengan indikator & 3 & Valid \\
\hline & $\begin{array}{l}\text { 3. Batasan peryataan dirumuskan dengan } \\
\text { jelas }\end{array}$ & 3,5 & $\begin{array}{r}\text { Sangat } \\
\text { Valid }\end{array}$ \\
\hline \multicolumn{2}{|r|}{ Nilai Rata-rata Aspek II } & 3,16 & Valid \\
\hline \multirow{3}{*}{ III } & Aspek Bahasa & & \\
\hline & $\begin{array}{l}\text { 1. Menggunakan bahasa Indonesia yang } \\
\text { benar dan jelas }\end{array}$ & 3 & Valid \\
\hline & $\begin{array}{l}\text { 2. Menggunakan Kalimat yang sederhana } \\
\text { dan mudah dimengerti. }\end{array}$ & 3 & Valid \\
\hline \multicolumn{2}{|r|}{ Nilai Rata-rata Aspek III } & 3 & Valid \\
\hline \multicolumn{2}{|r|}{ Rata-rata Total } & 3,05 & Valid \\
\hline
\end{tabular}

Hasil nilai rata-rata total validasi angket aktivitas tabel adalah 3.00. angket aktivitas peserta pelatihan sesuai tabel katagori validasi di katagorikan valid. Rangkuman hasil validasi angket aktivitas tabel dapat dilihat pada tabel III.

Tabel III

Hasil Validasi Angket Aktivitas Peserta Pelatihan

\begin{tabular}{|c|c|c|c|}
\hline No & URAIAN & RERATA & KET \\
\hline \multirow{3}{*}{ I } & Aspek Petunjuk & & \\
\hline & $\begin{array}{l}\text { 1. Petunjuk lembar angket respon peserta } \\
\text { didik dinyatakan dengan jelas. }\end{array}$ & 3 & Valid \\
\hline & $\begin{array}{l}\text { 2. Kriteria penilaian dinyatakan dengan } \\
\text { jelas. }\end{array}$ & 3 & Valid \\
\hline & Nilai Rata-rata Aspek I & 3 & Valid \\
\hline \multirow{4}{*}{ II } & Aspek Cakupan & & \\
\hline & $\begin{array}{l}\text { 1. Sesuai dengan tujuan angket respon } \\
\text { peserta didik }\end{array}$ & 3 & Valid \\
\hline & 2. Pernyataan sesuai dengan indikator & 3 & Valid \\
\hline & jelas & & \\
\hline & Nilai Rata-rata Aspek II & 3 & Valid \\
\hline \multirow{3}{*}{ III } & Aspek Bahasa & & \\
\hline & $\begin{array}{l}\text { 1. Menggunakan bahasa Indonesia yang } \\
\text { benar dan jelas }\end{array}$ & 3 & Valid \\
\hline & $\begin{array}{l}\text { 2. Menggunakan Kalimat yang sederhana } \\
\text { dan mudah dimengerti. }\end{array}$ & 3 & Valid \\
\hline \multicolumn{2}{|r|}{ Nilai Rata-rata Aspek III } & 3 & Valid \\
\hline & Rata-rata Total & 3 & Valid \\
\hline
\end{tabular}

Hasil nilai rata-rata total validasi angket aktivitas peserta pelatihan adalah 3.08. angket aktivitas pelatih sesuai tabel katagori validasi di katagorikan valid. Rangkuman hasil validasi angket aktivitas pelatih dapat dilihat pada tabel IV. 
Tabel Iv

Hasil Validasi Angket Aktivitas Pelatihan

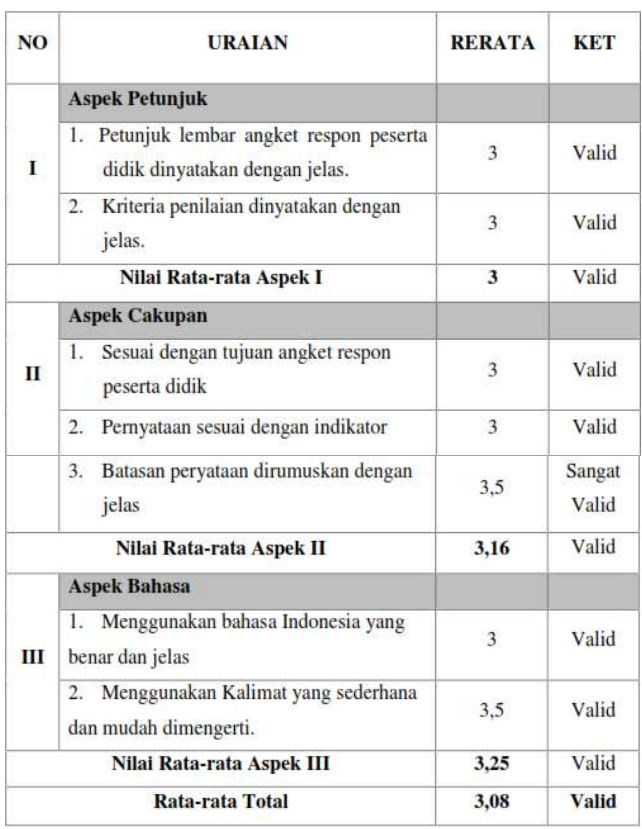

Hasil nilai rata-rata total validasi kisi-kisi dan soal pre-post tes pengetahuan elektronika dasar peserta pelatihan adalah 3.04. Angket tersebut sesuai tabel katagori validasi di katagorikan valid. Rangkuman hasil validasi kisi-kisi dan soal pre-post tes dapat dilihat pada tabel V.

Tabel V

Hasil Validasi Kisi-Kisi Dan Soal Pre-Post Test

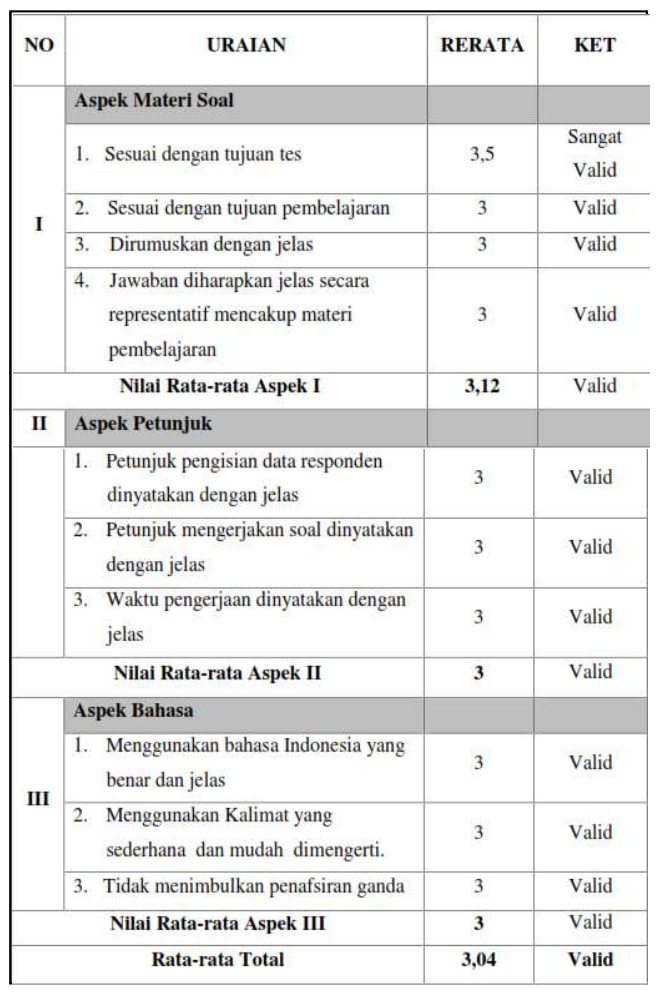

\section{A. Uji coba subjek penelitian}

Uji coba subjek penelitian meliputi uji coba keterbacaan oleh beberapa remaja, uji coba kelompok kecil, uji coba lebih luas.

1) Uji coba perorangan: Uji coba keterbacaan dilakukan terhadap 3 (tiga) remaja pesisir desa bontopannu dan diperoleh hasil nilai rata-rata 3,35 termasuk dalam katagori sangat baik.

$$
\text { Tabel Vi }
$$

Hasil Uji Coba Perorangan

\begin{tabular}{|c|c|c|c|c|c|c|}
\hline \multirow[b]{2}{*}{ No } & \multirow{2}{*}{ URAIAN } & \multicolumn{3}{|c|}{ RESPONDEN } & \multirow{2}{*}{$\begin{array}{l}\text { RATA- } \\
\text { RATA }\end{array}$} & \multirow[t]{2}{*}{ KET } \\
\hline & & 1 & 2 & 3 & & \\
\hline 1 & 2 & 3 & 4 & 5 & 6 & 7 \\
\hline 1 & $\begin{array}{l}\text { Pemilihan media pembelajaran sangat } \\
\text { menark }\end{array}$ & 3 & 2 & 4 & 3 & Sangat balik \\
\hline 2 & Media pembelajaran terilihat jelas & 3 & 3 & 3 & 3 & Sangat baik \\
\hline 3 & Suara media pembelajaran terdengar jelas & 4 & 3 & 4 & 3.67 & Sangat balk \\
\hline 4 & Besar huruf teks mudah terbaca & 3 & 3 & 4 & 3.53 & Sengat baik \\
\hline 5 & $\begin{array}{l}\text { Media pembelajaran prakts dan mudah } \\
\text { digunakan }\end{array}$ & 4 & 4 & 4 & 4 & Sengat baik \\
\hline 6 & $\begin{array}{l}\text { Media pembelajaran dapat menambah } \\
\text { semangat belajar }\end{array}$ & 3 & 4 & 3 & 3.33 & Sangat baik \\
\hline 7 & $\begin{array}{l}\text { Media pembelajaran memudahikan saya } \\
\text { memahani pelajaran }\end{array}$ & 4 & 4 & 4 & 4 & Sangat baik \\
\hline 8 & $\begin{array}{l}\text { Pembelajaran titorial keteramplan } \\
\text { elektronika mendorong saya untuk belagiar } \\
\text { lebăh baik dari biasanya }\end{array}$ & 3 & 3 & 3 & 3 & Sangat baik \\
\hline 9 & $\begin{array}{l}\text { Media pentibelajaran tutorial menambah } \\
\text { interaksi saya dengan pelath saya }\end{array}$ & 4 & 3 & 4 & 3.67 & Sengat baik \\
\hline 10 & $\begin{array}{l}\text { Media pembelajaran tutorial menambah } \\
\text { interaksi saya dengan teman kelas saya }\end{array}$ & 3 & 3 & 1 & 2.33 & Baik \\
\hline 11 & $\begin{array}{l}\text { Media pembelajaran dapat menambah } \\
\text { pengetehuan saya }\end{array}$ & 4 & 4 & 4 & 4 & Sangat baik \\
\hline 12 & $\begin{array}{l}\text { Media pembeliajaran mengangkat rasa } \\
\text { percaya dri dalam belajar }\end{array}$ & 4 & 3 & 3 & 3.33 & Sangat baik \\
\hline 13 & $\begin{array}{l}\text { Media pembelajaran yang disajikan bidak } \\
\text { membuat saya bosan }\end{array}$ & 3 & 4 & 4 & 3.67 & Sangat baik \\
\hline 14 & $\begin{array}{l}\text { Media pembelajaran tutorial membantu saya } \\
\text { belajar mandiri }\end{array}$ & 3 & 3 & 4 & 3.33 & Sengat baik \\
\hline 15 & $\begin{array}{l}\text { Media pembelajaran memungkinkan saya } \\
\text { tidak menggunakan media pembelajaran } \\
\text { yang lain. }\end{array}$ & 2 & 2 & 1 & 1.67 & Kurang Baik \\
\hline 16 & $\begin{array}{l}\text { Media pembelajaran memotivasi saya dalam } \\
\text { belajar }\end{array}$ & 4 & 4 & 3 & 3.67 & Sangat baik \\
\hline 17 & $\begin{array}{l}\text { Media pembelajaran dapat mengembangkan } \\
\text { kemanquan saya dalam keteramplan } \\
\text { elektronika }\end{array}$ & 4 & 4 & 4 & 4 & Sangat baik \\
\hline 18 & $\begin{array}{l}\text { Media pembelajaran dapat membantu } \\
\text { prestasi belajar saya }\end{array}$ & 3 & 3 & 3 & 3 & Sengat baik \\
\hline 19 & Media pembelajaran perlu dikenbangkan & 4 & 3 & 4 & 3.67 & Sangat baik \\
\hline & Rata-rata & 3.42 & 3.26 & 3.37 & 3.351 & Sangat baik \\
\hline
\end{tabular}

2) Uji coba kelompok kecil: Setelah dilakukan uji coba keterbacaan selanjutnya adalah uji coba kelompok kecil. Uji coba ini dilakukan terhadap 6 (enam) orang dan diperoleh hasil nilai rata-rata 3,46 termasuk dalam katagori sangat baik. Sehingga dapat dilanjutkan ke tahap berikutnya, yaitu uji coba diperluas. Rangkuman hasil uji coba kelompok kecil dapat dilihat pada tabel VII. 
TABEL VII HASIL UJI COBA KELOMPOK KECIL

\begin{tabular}{|c|c|c|c|c|c|c|c|c|c|}
\hline \multirow{2}{*}{ No } & \multirow{2}{*}{ Uraian } & \multicolumn{6}{|c|}{ Responden } & \multirow{2}{*}{ Rerata } & \multirow{2}{*}{ Ket. } \\
\hline & & 1 & 2 & 3 & 4 & 5 & 6 & & \\
\hline 1 & 2 & 3 & 4 & 5 & 6 & 7 & 8 & 9 & 10 \\
\hline 1 & $\begin{array}{l}\text { Pemilihan media pembelajaran sangat } \\
\text { menarik }\end{array}$ & 4 & 4 & 3 & 4 & 4 & 4 & 3.83 & Sangat Baik \\
\hline 2 & Media pembelajaran terlihat jelas & 3 & 3 & 3 & 3 & 3 & 3 & 3 & Sangat Baik \\
\hline 3 & $\begin{array}{l}\text { Suara media pembelajaran terdengar } \\
\text { jelas }\end{array}$ & 3 & 4 & 4 & 4 & 4 & 4 & 3.83 & Sangat Baik \\
\hline 4 & Besar huruf teks mudah terbaca & 4 & 3 & 4 & 4 & 4 & \begin{tabular}{|l|l}
3 & \\
\end{tabular} & 3.67 & Sangat Baik \\
\hline 5 & $\begin{array}{l}\text { Media pembelajaran praktis dan mudah } \\
\text { digunakan }\end{array}$ & 4 & 4 & 3 & 3 & 3 & 2 & 3.17 & Sangat Baik \\
\hline 6 & $\begin{array}{l}\text { Media pembelajaran dapat menambah } \\
\text { semangat belajar }\end{array}$ & 4 & 4 & 4 & 4 & 4 & 3 & 3.83 & Sangat Baik \\
\hline 7 & $\begin{array}{l}\text { Media pembelajaran memudahkan saya } \\
\text { memahami pelajaran }\end{array}$ & 3 & 4 & 4 & 4 & 4 & 3 & 3.67 & Sangat Baik \\
\hline 8 & $\begin{array}{l}\text { Pembelajaran tutorial keterampilan } \\
\text { elektronika mendorong saya untuk } \\
\text { belajar lebih baik dari biasanya }\end{array}$ & 4 & 4 & 4 & 4 & 3 & 3 & 3.67 & Sangat Baik \\
\hline 9 & $\begin{array}{l}\text { Media pembelajaran tutorial menambah } \\
\text { interaksi saya dengan pelatih saya }\end{array}$ & 4 & 3 & 4 & 3 & 3 & 3 & 3.33 & Sangat Baik \\
\hline 10 & $\begin{array}{l}\text { Media pembelajaran tutorial menambah } \\
\text { interaksi saya dengan teman kelas saya }\end{array}$ & 3 & 3 & 3 & 4 & 3 & 3 & 3.17 & Sangat Baik \\
\hline 11 & $\begin{array}{l}\text { Media pembelajaran dapat menambah } \\
\text { pengetahuan saya }\end{array}$ & 4 & 4 & 4 & 4 & 4 & 4 & 4 & Sangat Baik \\
\hline 12 & $\begin{array}{l}\text { Media pembelajaran mengangkat rasa } \\
\text { percaya diri dalam belajar }\end{array}$ & 4 & 4 & 3 & 3 & 3 & 4 & 3.5 & Sangat Baik \\
\hline 13 & $\begin{array}{l}\text { Media penbelajaran yang disajikan tidak } \\
\text { membuat saya bosan }\end{array}$ & 4 & 3 & 3 & 3 & 4 & 3 & 3.33 & Sangat Baik \\
\hline 14 & $\begin{array}{l}\text { Media pembelajaran tutorial membantu } \\
\text { saya belajar mandiri }\end{array}$ & 4 & 3 & 4 & 4 & 4 & 3 & 3.67 & Sangat Baik \\
\hline 15 & $\begin{array}{l}\text { Media pembelajaran memungkinkan } \\
\text { saya tidak menggunakan media } \\
\text { pembelaiaran yyang lain. }\end{array}$ & 3 & 3 & 1 & 2 & 2 & 2 & 2.17 & Baik \\
\hline 16 & $\begin{array}{l}\text { Media pembelajaran memotivasi saya } \\
\text { dalam belajar }\end{array}$ & 3 & 4 & 3 & 3 & 4 & 3 & 3.33 & Sangat Baik \\
\hline 17 & $\begin{array}{l}\text { Media pembelajaran dapat } \\
\text { mengeembangakan kemanpuan saya } \\
\text { dalam keterampilan elektronika }\end{array}$ & 4 & 4 & 3 & 4 & 4 & 3 & 3.67 & Sangat Baik \\
\hline 18 & $\begin{array}{l}\text { Media pembelajaran dapat membantu } \\
\text { prestasis belajar saya }\end{array}$ & 3 & 4 & 3 & 4 & 4 & 3 & 3.5 & Sangat Baik \\
\hline \multirow[t]{2}{*}{19} & Media pembelajaran perlu dikembangkan & 4 & 4 & 4 & 3 & 3 & 3 & 3.5 & Sangat Baik \\
\hline & Rata-Rata & 3.6 & 3.6 & 3.4 & 3.5 & 3.5 & 3.1 & 3.46 & $\begin{array}{c}\text { Sangat } \\
\text { Baik }\end{array}$ \\
\hline
\end{tabular}

3) Uji coba diperluas: Uji coba lebih luas ini dilakukan dalam 3 (tiga) kali pertemuan. Pelatih membawakan materi ajar dasar elektronika dengan menggunakan media pembelajaran teknik perawatan dan perbaikan alat telekomunikasi. Dua video tutorial setiap sub bagian materi baik software maupun hardware. Rangkuman hasil uji coba diperluas dapat dilihat pada tabel VIII.

Tabel Viii

Hasil Uji Coba Diperluas

\begin{tabular}{|c|c|}
\hline Total rata-rata & Katagori \\
\hline 3,38 & Sangat baik \\
\hline
\end{tabular}

Hasil analisis respon tabel menunjukkan bahwa media pembelajaran teknik perawatan dan perbaikan alat telekomunikasi dengan nilai total rata-rata 3,38 dalam katagori sangat baik. Sehingga disimpulkan bahwa media pembelajaran keterampilan elektronika dari hasil pengembangan direspon positif oleh remaja Desa Bontopannu Kab. Gowa.

Implementation

Tahap penelitian selanjutnya yaitu mengimplementasikan hasil yang telah diperoleh. Membuat produk akhir media pembelajaran perawatan dan perbaikan alat telekomunikasi menggunakan autoplay 7.0 dari hasil revisi, agar media pembelajaran ini dapat lebih maksimal digunakan dalam proses pembelajaran. Setelah itu dilakukanlah sosialisasi tentang efektifitas dan efisien media pembelajaran perawatan dan perbaikan alat telekomunikasi dalam proses belajar mengajar di Desa Bontopannu Kab. Gowa

\section{KESIMPULAN}

1. Proses pengembangan bahan ajar keterampilan elektronika dengan menerapkan media pembelajaran bahan ajar menggunakan software Autoplay 7.0 dilaksanakan dengan menggunakan model rancangan sistem pembelajaran yang digunakan adalah model ADDIE. Model ini terdiri dari lima fase atau tahap utama, yaitu Analysis, Desain, Development, Implementation, dan Evaluation.

2. Hasil analisis respon tabel pada uji coba diperluas menunjukkan bahwa pembelajaran menggunakan autoplay 7.0 pada keterampilan elektronika teknik perawatan dan perbaikan alat telekomunikasi memiliki rerata $\mathbf{3 , 3 8}$ dan katagori sangat baik. Sehingga disimpulkan bahwa media pembelajaran hasil pengembangan direspon positif oleh masyarakat pesisir/remaja di Desa Bontopannu Kab. Gowa.

3. Hasil konseptual dan produk fisik yang dihasilkan dari pembelajaran ini adalah $C D$ Tutorial, Buku panduan penggunaan media dan Buku Ajar . Dimana memudahkan orang awam dalam hal penggunaan media tersebut.

4. Bahan ajar dengan penerapan media pembelajara menggunakan software autoplay 7.0 pada proses pembelajaran kelompok remaja di Desa Bontopannu dinyatakan valid, praktis dan efektif penggunaan media pembelajaran di Desa Bontopannu khususnya kelompok remaja. Karena hasil validasi ahli materi dengan total nilai rata-rata total 3,19 berada dalam katagori valid dan hasil validasi ahli media dengan toal nilai rata-rata $\mathbf{3 , 2 3}$ berada pada katagori valid. Dari hasil analisis respon pelatih dan tabel dalam katagori sangat baik, sehingga dinyatakan praktis digunakan dalam pembelajaran. Hasil analisis data aktivitas tabel dan tabel dikatagorikan sangat baik, sehingga dapat dinyatakan efektif digunakan dalam pembelajaran.

\section{DAFTAR PUSTAKA}

[1] Angkowo, Robertusdan A. Kosasih.2007. Optimalisasi Media Pembelajaran. Jakarta: PT. Grasindo.

[2] Arsyad, Azhar.2002. Media Pembelajaran. Jakarta: PT. Raja Grafindo Persada.

[3] Bovee and Thull. 1997. Business Communication On Blog.(http://boveeandthillbusinesscommunicationblo g.com/), diakses tanggal 02 Juni 2019

[4] Briggs,J.L. (1997). Instruction Design; Penciple and Aplication. New York: Educational Technology Publication Inc.

[5] Gafur A. 2004. Pedoman Penyusunan Materi Pembelajaran (Instructional Material. Jakarta: Depdiknas 
Jurnal MediaTIK : Jurnal Media Pendidikan Teknik Informatika dan Komputer

[6] Gerlach, Vernon S. \& Donald P. Ely. 1980. Teaching \& Media: A Systematic Approach. Second edition. Englewood Cliffs, New Jersey: Prentice Hall, Inc

[7] Hartoyo.2009. Pengembangan Modul Pembelajaran Mata Kuliah Teknik Elektronika Dasar Berbasis Kompentensi sebagai Upaya untuk Meningkatkan Prestasi Belajar Mahasiswa. Yogyakarta: Jurnal Edukasi@, Elektro Volume 5, Nomor 1.

[8] Mulyasa, E. 2006. Menjadi Guru Profesional Menciptakan Pembelajaran Kreatif dan Menvenangkan. Bandung: Remaja Rosdakarya.

[9] Mulyasa E. 2006. Kurikulum Yang Disempurnakan. Bandung: PT Remaja Rosdakarya

[10] Panen, P \& Purwanto, 1997. Penulisan Bahan Ajar. Jakarta: Ditjen Dikti Depdikbud

[11] Rusman. 2011. Model-model Pembelajaran. Jakarta: PT. Raja Grafindo Persada.

[12] Rusman.2012. Pembelajaran Berbasis Teknologi Informasi dan Komunikasi Mengembangkan Profesionalitas Guru. Jakarta: PT. Raja Grafindo Persada.

[13] Schramm, W. 1964. Mass Media and National Development. Paris: UNESCO.

[14] Semiawan, Conny R. 2007. Landasan Pembelajaran dalam Perkembangan Manusia. Jakarta : Centre of Human Competency Development 